\title{
Kościelna afirmacja człowieka afirmacją prawa. Od Jana Pawła II do Benedykta XVI
}

Ksiądz Jerzy Bajda w uprawianej przez siebie teologii był mocno związany z nauczaniem św. Jana Pawła II, a zwłaszcza z jego koncepcją osoby oraz małżeństwa i rodziny, a także z wynikającego z tej koncepcji kluczowego obowiązku obrony życia od poczęcia do naturalnej śmierci. Ponieważ taki jest najbardziej podstawowy sens jego wypowiedzi teologicznych, dlatego zostaje zaproponowana refleksja teologiczna nad zagadnieniem, które może być uznane z najbardziej podstawowy kontekst jego teologii, pozwalający dobrze ją usytuować oraz określić jej perspektywę.

\section{Teologia i prawo}

W 1612 roku Włoch Alberico Gentili, jeden z pionierów współczesnego prawa międzynarodowego,
- Teologia i prawo

- Współczesny kontekst prawny

- Zaczynać od osoby

- Niebezpieczeństwa do zauważenia

- Propozycje 
z wysokości swojej katedry profesorskiej w Oxfordzie, twardo i z nieukrywaną pychą, grzmiał: „Silete theologi in munere alieno”' W wolnym tłumaczeniu można to oddać następująco: „Teologowie, nie wtrącajcie się w nieswoje sprawy, a zwłaszcza trzymajcie się z daleka od prawa”. To strofowanie $\mathrm{z}$ równą mocą zdaje się rozbrzmiewać także w naszych czasach. Wiemy dobrze, że liczne współczesne teorie prawa są negatywnie nastawione nie tylko do teologii, lecz także do metafizyki i filozofii tout court. Zdaje się, że nie jest to opinia powszechna, skoro $\mathrm{w}$ tym "miejscu prawnym” pozwala się skromnemu teologowi powiedzieć coś o teologach. Za takich można uznać zarówno papieża Jana Pawła II, jak i Benedykta XVI, chociaż ich wypowiedzi, sytuujące się na linii wypełniania „ministerium Petrinum”, przekraczają zdecydowanie status jakiejś tylko zwyczajnej teologii. Przysługuje im szczególny autorytet doktrynalny, gdyż wpisują się w pełnienie najwyższego urzędu nauczycielskiego w Kościele. Co więcej, kwestia prawa nie była obca Janowi Pawłowi II ani kard. Josephowi Ratzingerowi, zanim został wybrany następcą Piotra w Kościele. Ani jeden, ani drugi nie poddali się rozmaitym i wielorakim naciskom, za których pomocą usiłowano zmusić ich do milczenia. Spotkało się to w końcu także z uznaniem akademickim, którego wyrazem stało się przyznanie im doktoratów honoris causa właśnie za wkład $\mathrm{w}$ dziedzinę prawa. Janowi Pawłowi II taki doktorat przyznał Uniwersytet Rzymski „La Sapienza” (17.05.2003)², a kard. Josephowi Ratzingerowi Wydział Jurysprudencji na Uniwersytecie Matki Bożej Wniebowziętej w Rzymie (10 listopada 1999 roku) ${ }^{3}$.

Dzisiaj nie uważa się już teologii, jak to było w minionych epokach, za szczyt wszelkiej wiedzy, a status naukowy, społeczny, a nawet kościelny teologa nie jest afirmowany bezwarunkowo. Co więcej, w różnych kręgach coraz częściej wyraża się przekonanie, że teologia powinna być traktowana jako wiedza „wydzielona”. Owszem, jest ona cenna d la Kościoła i w Kościele, niech zatem także Kościół strzeże jej zazdrośnie przed zawirowaniami i wirusami współczesności, ale niech z nią nie wychodzi na zewnątrz, by podejmować konfrontację z aktualną rzeczywistością i jej wyzwaniami. W tym nurcie myślenia teolog jest traktowany jako ktoś, kto o sprawach tego świata

1 A. Gentili, De iure belli I, 12.

2 Por. Giovanni Paolo II, le vie della giustitia. Itinerari per il terzo millennio. Omaggio di Sua santita nel XXV anno di pontificato, red. A. Loiodice, M. Vari, Roma 2003.

3 Por. Per il diritto. Omaggio a Joseph Ratzinger e Sergio Cotta, Torino 2000. 
ma niewiele do powiedzenia; widzi się go jako specjalistę od jakichś kwestii niemal ezoterycznych, które należą do innego świata. Osobiste zaangażowanie i dzieło teologiczne papieża Jana Pawła II i kard. Josepha Ratzingera nie ugięło się pod naciskiem tych poglądów i wyraziło się jako zdecydowany sprzeciw. Obaj papieże wyszli z założenia, że na gruncie solidnej i krytycznej teologii trzeba zmierzyć się z kontrowersyjną współczesnością, nie domagając się dla teologii jakiejś funkcji hegemonicznej. Odwołując się do jej wewnętrznej siły, podjęli działania zmierzające do dynamicznego wejścia $\mathrm{z}$ nią $\mathrm{w}$ zsekularyzowany świat i twórczego zmierzenia się z nim - światem dalekim od tego, by żywić sympatię dla teologii lub okazywać jej jakieś specjalne zainteresowanie. Ich dyskurs teologiczny, wrażliwy oczywiście na potrzeby dzisiejszego wierzącego, jest nie tylko apologetyczny, parenetyczny czy pocieszający. Jak każdy inteligentny dyskurs, jest on także - można by powiedzieć za św. Augustynem - czymś w rodzaju „tinea ossibus”, czyli „kornikiem", który nieustannie wykonuje swoją pracę i który w demaskowaniu idoli staje się bardziej żrący niż rdza. Świat i człowiek nie potrzebują przecież łatwej aprobaty i ślizgania się po powierzchni problemów, a teologiczne, czyli „sub ratione Dei”, dogłębne wnikanie w ludzką rzeczywistość nie upokarza rozumu, ale go broni; nie niszczy świata zamieszkałego przez człowieka, ale go oczyszcza i umacnia.

Częścią tej rzeczywistości ludzkiej jest także prawo, dlatego właśnie teo$\log$ - czy to się komuś podoba, czy nie - musi w nie wnikać i wypowiadać swój osąd nad jego stanem i jego propozycjami. Olbrzymią dawkę takiego osądu znajdujemy w nauczaniu Jana Pawła II, który wielokrotnie przemawiał do prawników, do czego był zobowiązany zarówno jako prawodawca kościelny, jak również jako wychowawca osób i całych społeczeństw, wychodzący z przekonania, że prawo odgrywa podstawową rolę w życiu społecznym i politycznym. Można by wyprowadzić z jego wypowiedzi kompletną, filozoficzną i teologiczną teorię prawa. Kard. Ratzinger wiele uwagi poświęcił kwestiom związanym z prawem, wielokrotnie - zwłaszcza w ostatnich latach - wypowiadając się na temat współczesnych problemów społecznych, politycznych i kulturowych. Wywodzący się ze szkoły św. Augustyna, który prawo traktował trochę jako „zło konieczne”, kard. Ratzinger nie uczynił z prawa ulubionej dziedziny swojej refleksji, dlatego też jego wypowiedzi nie mają charakteru systematycznego. Jednak na uwagę zasługuje zaprezentowana przez niego krytyka niektórych założeń i schematów funkcjonujących 
we współczesnych teoriach prawa i w jego aplikacjach prawodawczych, jak również niektóre propozycje takiego kształtowania człowieka, któremu nie będzie obca wrażliwość prawna.

W tym miejscu zwrócę uwagę na niektóre kwestie, które w dziedzinie prawa łączą papieży Jana Pawła II i kard. Ratzingera, a mianowicie: 1. wpływ współczesnego kontekstu kulturowego na destrukcję pojęć prawa i sprawiedliwości; 2 . wizja człowieka-osoby jako punkt wyjścia prawa; 3 . niektóre krytyczne momenty współczesnych interpretacji prawa.

\section{Współczesny kontekst prawny}

Już myśliciele średniowieczni - mimo że zarzuca się im brak wrażliwości historycznej - wiedzieli, że „variatio temporis determinat, non variat fidei”. Wydaje się, że to samo pryncypium powinno dotyczyć każdej innej dziedziny życia ludzkiego, to znaczy: może się zmieniać sposób wyrażania jakiegoś aspektu naszego życia, ale nie powinna ulec zmianie jego istota. Dzisiaj - niestety - często dzieje się tak, że zmieniające się czasy widzi się jako uzasadnienie dla zmiany wszystkiego, czym żyje człowiek, i to zmiany sięgającej samej istoty rzeczy. Także $\mathrm{w}$ dziedzinie prawa traci sens to, o czym kiedyś z głębokim przekonaniem mówił Spinoza: „Humanas actiones non ridere non lugere nec detestari sed intelligere". Dzisiaj podchodzi się do sprawy dokładnie odwrotnie.

Jak zatem upływ czasu wpływa dzisiaj na rozumienie samego prawa i jak to zjawisko może być zinterpretowane?

August Comte, którego poglądy odegrały decydujące znaczenie w ukształtowaniu aktualnego obrazu świata i doprowadziły do przyjęcia w nauce metody pozytywistycznej, odnosząc się do prawa, spójnie ze swoim programem filozoficznym pisał: „Pojęcie prawa musi zniknąć ze świata politycznego, tak jak pojęcie przyczyny ze świata filozoficznego, skoro te dwa pojęcia zakładają istnienie rzeczywistości absolutnej i bezdyskusyjnej”. Mówienie dzisiaj o czymkolwiek absolutnym, a zwłaszcza o prawach absolutnych, przeciwstawia się rozpowszechnionej dzisiaj mentalności, która, biorąc sobie głęboko do serca idee Comte’a, nie uznaje wartości transcendentnych, ahistorycznych i akulturowych.

Sakralna wizja wszechświata została już porzucona prawie wszędzie, a jej miejsce zajęła wizja zsekularyzowana. Co spowodowało tę zmianę? „Skała” 
nie jest już emblematycznym i profetycznym symbolem wiecznej niezmienności Boga, ale pozostała jedynie tym, czym była zawsze, czyli zwykłym materiałem budowlanym. Grzmot i huragan nie są już gniewnym głosem Jowisza, ale dźwiękowym efektem dekompresji atmosferycznej. Kosmos nie jest już widzialnym skutkiem tragicznych teogonii, ale po prostu wodorem, który przekształca się w hel. Człowiek - bo to wszystko ma wpływ na jego wizję nie jest już postrzegany jako ten, który został pomyślany i jest chciany przez Kogoś; nie jest więc tym, kto w nieogarnionym Kosmosie jest najbardziej podobny do Boga. Jest on niejako ubocznym produktem, ani nie chcianym ani nie kochanym, tej niezmiernej machiny, którą nazywamy Kosmosem.

Myślący pozytywistycznie Sartre pisał lapidarnie: „Człowiek rodzi się bez racji bycia; przedłuża swoje istnienie w słabości; kończy w zwyczajnej potyczce”. Człowiek prawdziwy, człowiek rzeczywisty, człowiek bez pocieszających mitów, jest iluzją optymistycznej paranoi oraz owocem spotkania się ze sobą przypadku i konieczności - prostym „błędem kosmicznym”, jak powiedziałby Jacques Monod. Przypomnijmy jednak sobie, co mówi Arystoteles. Otóż, wynik spotkania się sił pozbawionych celu może być opisany bardziej odpowiednio jako niebyt niż jako byt. Niebyt zaś nie może domagać się dla siebie jakichś praw. Tym niebytem, w takim ujęciu, jest człowiek, skoro w pozytywistycznej interpretacji jest wynikiem przypadku, produktem gry kosmicznej. W konsekwencji nie może domagać się dla siebie żadnych praw oraz tworzyć stałych norm. Tracą zatem sens także wszelkie teorie prawa, a jeśli mimo wszystko się je tworzy, to są one tylko rodzajem ćwiczenia umysłowego, które również nie ma żadnego określonego sensu. A przecież już człowiek archaiczny nie był w stanie uznać, że Wszechświat jest nonsensem. Sam Marks zauważył, że mówić o celowości oznacza otworzyć drzwi „roszczeniu", które jest ponad człowiekiem.

Sartre, stwierdziwszy, że człowiek pojawia się na scenie świata bez racji bytu, z godną pochwały konsekwencją wyeliminował ze swojego słownika słowo sprawiedliwość. Można wybrać raczej byt niż niebyt, ale czy można wybrać niebyt zamiast bytu? Wszyscy ci filozofowie, którzy uważają świat za nieożywioną magmę, aby pozostać wierni swoim założeniom, powinni podzielać radykalny pesymizm mędrców babilońskich, o których pisze Stephen Lougdon w Babilońskiej mądrości $i^{4}$. Jeśli historia powszechna

4 Por. S. Lugdon, Babylonian Wisdom, London 1923. 
jest tylko „stanem mentalnym” (karma), bez końca i bez celu, jeśli nasz Wszechświat jest tylko wielkim kołem, które kręci się, nie wiedząc ani „dlaczego", ani „jak”, to nie może istnieć jedno, obowiązujące wszystkich kryterium rozróżniania między aktami ludzkimi. Nie ma rzeczywistej i obiektywnej różnicy między życiem miłością i życiem nienawiścią, gdyż nie istnieje to, co miłowane, i to, co nienawidzone. Nie ma różnicy między życiem nikczemnym i życiem heroicznym; nie ma różnicy między wiernością i zdradą. Wszystko jest marnością.

\section{Zaczynać od osoby}

Jeśli chcemy umacniać prawa człowieka, a zarazem nie pozwolić, by stały się elementem gier ideologicznych lub utopijnych, które wręcz kwitną w dzisiejszym świecie, trzeba im nadać możliwie obiektywny i trwały punkt wyjścia i oparcia. Komentując przytoczone wyżej radykalne stwierdzenie Comte’a, Jacques Maritain w swoich pismach wielokrotnie podkreślał, że prawo służące sprawiedliwości musi być obiektywne, a jest takie jeśli odpowiada zasadom rozumu. Ma to miejsce wówczas, gdy prawo opiera się na absolutnej godności posiadanej przez osobę i gdy jest „ukierunkowane na Boga jako jego absolutny cel ostateczny"5. W takim przypadku można powiedzieć, że źródłem prawa jest Mądrość wyższa od świata, czyli taka, która stworzyła świat i go porządkuje.

Jest to obserwacja, która syntetyzuje chrześcijańskie doświadczenie $\mathrm{w}$ dziedzinie prawa i która także w ostatnim czasie stanowi punkt odniesienia nauczania Kościoła w tej dziedzinie.

Jedynym możliwym punktem wyjścia dla powszechnego i równego dla wszystkich prawa, a tym samym także dla sprawiedliwości jest uznanie, że świat został stworzony przez transcendentną Mądrość porządkującą. Tylko w Niej osoby, mając cele do osiągnięcia, mają również prawo do posiadania odpowiednich narzędzi, które te cele pozwalają osiągnąć. Jeśli Mądrość porządkująca nie istnieje, to nie istnieje również niesprawiedliwość. Będą mogły jeszcze istnieć ból i frustracja, ale będą miały znaczenie tylko

5 J. Maritain, La persone et le bien commun, w: J. et R. Maritain, Oeuvres completes, vol. 9, Fribourg/Suisse-Paris 1995, s. 973. 
przypadłościowe. Można wprawdzie szukać rozmaitych środków znieczulających, ale nie można protestować przeciw niesprawiedliwości. Jeśli człowiek jest polimorficzną magmą, to nie ma praw, ale tylko jakieś odczucia i stany ducha, a te nie mogą być źródłem uzasadnienia jakiegokolwiek powszechnego roszczenia.

Dziękując za przyznanie doktoratu honoris causa przez rzymski Uniwersytet Sapienza, papież Jan Paweł II dokonał swoistego podsumowania swojego wkładu w dziedzinę prawa. Mówił między innymi:

W swojej działalności kierowałem się zasadą, że osoba ludzka, taką jaką stworzył Bóg, jest fundamentem i celem życia społecznego, któremu prawo winno służyć. „Ideę, że człowiek stanowi centrum systemu prawnego, bardzo trafnie wyraża klasyczna formuła: Hominum causa omne ius consitutum est. Znaczy to, że prawo jest prawem w takiej mierze, w jakiej jego fundamentem jest człowiek i prawda o nim". Istotą prawdy o człowieku jest właśnie to, że został on stworzony na obraz i podobieństwo Boże. Człowiek jako „osoba” - według głębokiej myśli św. Tomasza z Akwinu „id quod est perfectissimum in tota natura”. Opierając się właśnie na tym przekonaniu, Kościół wypracował swą doktrynę o „prawach człowieka”, których źródłem nie jest państwo czy jakakolwiek inna władza, lecz sama osoba. Władza publiczna zatem powinna te prawa „uznać, szanować, uzgadniać, chronić i szerzyć", są to bowiem prawa „uniwersalne, nienaruszalne i niezbywalne”. Dlatego też „chrześcijanie powinni nieustannie pracować nad tym, by bardziej podkreślić godność, jaką człowiek obdarzony został przez Stwórcę, i wespół z innymi podejmować starania, by ją chronić i umacniać".

Wcześniej, przemawiając do przewodniczących parlamentów Unii Europejskiej i nawiązując do projektu Karty praw podstawowych Unii Europejskiej, papież mówił:

Przyjmując tę nową kartę - jakkolwiek będzie się w przyszłości nazywać - Unia Europejska nie powinna zapominać, że jest kolebką idei osoby

6 Jan Paweł II, Przemówienie z okazji nadania doktoratu honoris causa Uniwersytetu "La Sapienza" (17 maja 2003), "L'Osservatore Romano” 24 (2003) nr 10, s. 34. 
i wolności oraz że te idee ukształtowały się pod wpływem długiego oddziaływania chrześcijaństwa. W przekonaniu Kościoła osoba jest nierozerwalnie związana ze społeczeństwem, w którym się rozwija. Stwarzając człowieka, Bóg wpisał go w porządek relacji, które pozwalają mu na samorealizację. Porządek ten nazywany jest porządkiem naturalnym, zaś zadaniem rozumu jest zgłębianie go i coraz dokładniejsze opisywanie. Prawa człowieka nie mogą wyrażać dążeń sprzecznych z naturą człowieka. Mogą jedynie z niej wypływać ${ }^{7}$.

Przyjęcie osoby stworzonej przez Boga jako podmiotu prawnego i pierwszej zasady prawa ma wiele konsekwencji prawnych, prawodawczych i jurysprudencyjnych. Pomijając szczegółowy wykład na ten temat, który nie jest zadaniem teologa, wystarczy tutaj zwrócić uwagę na kwestię najbardziej zasadniczą. Przyjęcie takiego założenia kształtuje świadomość, że człowiek (prawodawca) nie tworzy prawa, ustaw, norm, zasad, sankcji, wskazań, ale je odkrywa - lub odkrywa na nowo - sięgając w głąb bytu ludzkiego i analizując jego wewnętrzne roszczenia. W tym sensie papież Jan Paweł II mówił o „prawdzie o osobie” jako źródle prawa. Pierwszą kwestią prawną jest kwestia źródła - początku prawa, kwestia, która dzisiaj, w epoce późno-pozytywistycznej, staje się coraz mniej doceniana i analizowana na gruncie filozofii prawa. Tymczasem to jest właściwa droga do wykroczenia poza prawo widziane tylko jako zbiór ustaw obwarowanych sankcjami. To jest droga do ukazania władzy jako prawnie gwarantowanej, a nie tylko udzielonej (czasowo). To jest droga do prawa podstawowego, a nie tylko opartego na powszechnej woli. W końcu, to jest droga do wartości zakorzenionych, a nie tylko deklarowanych. Tylko idąc tą drogą, można uniknąć awanturnictwa prawodawczego, które w dzisiejszym świecie jest na porządku dziennym, także w Polsce.

\section{Niebezpieczeństwa do zauważenia}

W nauczaniu papieża Jana Pawła II oraz refleksji kard. Ratzingera znajdujemy zdemaskowanie słabych stron prawa, które nie uwzględnia integralnej,

7 Jan Paweł II, Przemówienie do przewodniczq̨cych parlamentów Unii Europejskiej (23 września 2000), 4, "L'Osservatore Romano" 22 (2001) nr 1, s. 45. 
filozoficznej i teologicznej, antropologii. Prawo bez prymatu osoby w wyżej wskazanym sensie naraża się na różne niebezpieczeństwa, które mają także znaczący wymiar teologiczny, a więc dotyczą nie tylko prawników, lecz także teologów. Dlatego też teolog jest zobowiązany do ich podjęcia, jeśli chce spełniać adekwatną posługę kościelną i społeczną.

a) „Koniec metafizyki”, który - w duchu pozytywizmu - jest założony jako nieodwracalny fakt na wielu obszarach filozofii współczesnej, doprowadził do „pozytywizmu prawnego”. W dzisiejszych demokracjach wyraża się on przede wszystkim na gruncie „teorii zgodności”, w duchu „zgody społecznej”, zaproponowanej przez myślicieli oświeceniowych. W takim ujęciu źródłem prawa, jeśli rozum nie może już znaleźć drogi do metafizyki, stają się dla prawodawcy (państwa) tylko wspólne przekonania dotyczące wartości, reprezentowane przez obywateli - przekonania, które odzwierciedlają się w „zgodności demokratycznej”. Nie prawda tworzy więc zgodność, jak było w klasycznym prawie, ale to raczej zgodność tworzy nie tyle prawdy, ile wspólne normy i wskazania. Większość określa to, co ma wartość, jako prawdziwe i sprawiedliwe. Oznacza to, że prawo zostaje wystawione na grę większości i zależy od świadomości wartości w konkretnym społeczeństwie, na co wpływa oczywiście wiele czynników. Konkretnie wyraża się to w stopniowym zanikaniu podstaw prawa, zainspirowanych tradycją chrześcijańską. Przykładów można podać wiele: małżeństwo i relacja między mężczyzną i kobietą, sens niedzieli, szacunek dla Boga itd.

Ponieważ w nowoczesnych demokracjach, zarówno metafizyka, jak i ściśle z nią związane prawo naturalne właściwie straciły rację bytu, dlatego zachodzą szybkie i głębokie transformacje prawa. Do czego to doprowadzi, jeszcze nie wiadomo, chociaż jest pewne, że idą one w błędnym kierunku. Widać to choćby w rozmywaniu się pojęcia prawa oraz obniżaniu stopnia jego normatywności.

Jeśli można by wskazać jakiś precedens tego zjawiska, to w największym stopniu byłaby nim przemiana prawa, która następowała w późnym Bizancjum. Bizantynizacja prawa miała wszystkie cechy dzisiejszego pozytywizmu prawnego. Był to niebagatelny czynnik upadku tego imperium.

b) Drugie niebezpieczeństwo, na które naraża się dzisiaj prawo, również ma związek z teorią zgodności. Chodzi o rozmywanie prawa za pośrednictwem tego, co można by nazwać „duchem utopii”, który przybrał systematyczny i praktyczny kształt w myśli marksistowskiej. Punkt wyjścia tej utopii 
stanowi przekonanie, że aktualny świat jest zły - jest to świat wyzysku i ograniczonej wolności. Dlatego też powinien zostać on zastąpiony przez świat lepszy, zaplanowany i urzeczywistniany już teraz. Prawdziwym i ostatecznym źródłem prawa staje się obraz społeczeństwa nowego, poniekąd idealnego. Moralne i obdarzone mocą prawodawczą jest w takim ujęciu tylko to, co służy nadejściu nowego i lepszego świata. tona podstawie tego kryterium dokonała się przede wszystkim legitymizacja terroryzmu, który nadał sobie znamiona swoistego projektu moralnego. Morderstwo i przemoc są uzasadniane jako działania moralne, ponieważ służą wielkiej rewolucji, destrukcji aktualnego złego świata oraz wielkiemu ideałowi nowego społeczeństwa. Także w tym przypadku odrzuca się metafizykę. W jej miejsce wchodzi nie tylko zgodność współczesnych, lecz także idealny model przyszłego świata, który staje się najwyższą zasadą prawa.

Warto zauważyć, że już Paweł VI, a później także, od początku swojego pontyfikatu, Jan Paweł II wykazywali, że światu grozi niebezpieczeństwo terroryzmu, jeśli będzie ulegał utopijnym wizjom, które rodziły się na gruncie marksizmu. Kard. Ratzinger konsekwentnie występował przeciw teologii wyzwolenia, która jest jedną z tego typu utopii. Dzisiejszy terroryzm islamski w znacznym stopniu ma podobne pochodzenie i jest podobnie uzasadniany.

c) We współczesnej negacji prawa istnieje także nurt, który ma charakter poniekąd chrześcijański. Jest on propagowany na gruncie błędnego rozumienia tak zwanego paulinizmu, który pojawił się w radykalnych i anarchicznych nurtach interpretacji chrześcijaństwa. Szczególną uwagę zwrócił na niego kard. Ratzinger w swoich poszukiwaniach dotyczących istoty chrześcijaństwa.

Negacja tego typu ma związek z ruchami gnostyckimi, które wraz ze swoim „nie” dla Boga Stwórcy wypowiadają także „nie” w stosunku do metafizyki, prawa stworzonego i prawa naturalnego. Ta negacja łączy się ze wzbudzonymi w XVII wieku niepokojami i kontestacjami społecznymi, do których doprowadziły chrześcijańskie nurty reformistyczne o charakterze rewolucyjnym i utopijnym. Jednak najszerszy zasięg zyskały tendencje nastawione na poszukiwanie tak zwanego chrześcijaństwa duchowego i charyzmatycznego. Jest niewątpliwym paradoksem to, że tendencje te wyrosły i rozpowszechniły się w kręgach prawnych, a utrwaliły się dlatego, że ich przedstawieniom nadano pozory naukowości. Klasycznym reprezentantem tej tendencji jest wielki prawnik ewangelicki Rudolph Sohm, który zyskał wielu zwolenników także w Kościele katolickim. Sformułował on tezę, że chrześcijaństwo 
jako ewangelia, jako radykalne i zasadnicze zerwanie z Prawem Starego Testamentu, nie mogło i nie chciało wikłać się w żadne prawo. Kościół narodził się jako anarchia duchowa, która dopiero później, z powodu konieczności zewnętrznych wobec życia kościelnego, już pod koniec I wieku została zastąpiona przez prawo sakramentalne. W miejsce tego prawa, które niejako wyrastało z Ciała Chrystusa i miało naturę sakramentalną, w średniowieczu weszło prawo już nie Ciała Chrystusa, ale korporacji chrześcijan, czyli prawo kanoniczne, które istnieje do dnia dzisiejszego. Prawdziwym modelem życia chrześcijańskiego pozostawała dla Sohma anarchia duchowa, gdyż w idealnej kondycji Kościoła nie ma potrzeby żadnego prawa.

W XX wieku, wychodząc $\mathrm{z}$ tych założeń, stało się modne przeciwstawianie Kościoła prawa i Kościoła miłości, a więc prawo było przedstawiane jako przeciwieństwo miłości. Tego typu kontrast może - owszem - wyłonić się w konkretnej aplikacji prawa, ale podniesienie go do rangi zasady okazuje się destrukcyjne zarówno dla prawa, jak i miłości. Koncepcje tego typu mają ścisły związek z duchem utopii. Mimo dość oczywistej nielogiczności i tendencji ideologiczno-utopijnych są one szeroko rozpowszechnione w dzisiejszym społeczeństwie. W Polsce, w okresie komunistycznym, często wyśmiewano prawo i prawników, podnosząc do najwyższej prawną rangę „woli ludu pracującego" i prezentując ją jako najwyższe prawo w ramach tak zwanej dyktatury proletariatu. Warto zauważyć, że podobne traktowanie prawa było rozpowszechnione w narodowym socjalizmie w Niemczech hitlerowskich. Degradacja prawa nigdy nie służy wolności, ale zawsze jest narzędziem dyktatury, która pozornym demokratyzmem przykrywa swoje totalitarne działania.

Z zauważonych tutaj niebezpieczeństw, które zagrażają dzisiaj prawu, można wyprowadzić pewną prawidłowość: eliminacja metafizyki jest eliminacją osoby, a eliminacja osoby jest eliminacją prawa. Gdzie nie ma prawa, tam nie ma wolności, a więc autentycznego życia ludzkiego -nie ma człowieka.

\section{Propozycje}

Dostrzeżenie niebezpieczeństw i kontrowersyjnych ujęć jest oczywiście ważne, ale nie jest wystarczające. Potrzebna jest propozycja, która pozwoliłaby w sposób adekwatny stawić im czoło i wyjść z impasu. Takie propozycje 
zostały sformułowane w wypowiedziach prawnych papieża Jana Pawła II oraz w refleksji teologicznej kard. Josepha Ratzingera, obecnie papieża-seniora Benedykta XVI.

a) Na pierwszym miejscu znajduje się oczywiście naglące wezwanie do odbudowania metafizycznego statusu i sensu osoby, która jest „quaestio princeps" wszelkiej refleksji prawnej i wszelkich aplikacji prawodawczych. Wynika to z faktu, że tradycja chrześcijańska, idąc w znacznym stopniu po linii prawa rzymskiego, a przede wszystkim po linii teologii stworzenia, stwierdza jednoznacznie, że tylko afirmacja osoby otwiera drogę do afirmacji prawa oraz nadania mu wymiaru powszechnego i normatywnego. Aby takiej afirmacji osoby dokonać, trzeba powrócić z nową gorliwością do teologii stworzenia oraz odważnego wyprowadzania $\mathrm{z}$ niej konsekwencji antropologicznych. Na problem ten szczególnie zwracał uwagę kard. Ratzinger, podkreślając fundamentalne znaczenie tej teologii dla właściwego ujęcia kwestii moralnej, a zatem - co z tego wynika - również dla prawa. Papież Jan Paweł II mocno akcentował kwestię teologii osoby, która jest czymś w rodzaju antropologicznej koncepcji teologii stworzenia. Znaczenie tej kwestii wyraził profetycznie bardzo wcześnie, a mianowicie jeszcze w okresie krakowskim, w liście pisanym do Henriego de Lubaca z 1968 roku:

Moje bardzo rzadkie wolne chwile poświęcam pracy, która leży mi na sercu, a która jest poświęcona metafizycznemu znaczeniu i misterium OSOBY. Wydaje mi się, że debata rozgrywa się obecnie na tym polu. Zło naszych czasów polega na pierwszym miejscu na rodzaju degradacji, rozcieńczeniu fundamentalnej jedyności osoby ludzkiej. To zło ma miejsce bardziej w porządku metafizycznym niż moralnym. Tej niekiedy planowanej dezintegracji ze strony ideologii ateistycznych musimy przeciwstawić, zamiast bezpłodnych polemik, coś w rodzaju „rekapitulacji” nienaruszalnego misterium osoby ${ }^{8}$.

Jeśli chodzi o kwestię odbudowania metafizycznego statusu osoby, to trzeba zauważyć jej dwa specyficzne momenty, które dotyczą wkładu, jaki w obecnej sytuacji wiara i teologia mogą wnieść do obrony prawa.

8 H. de Lubac, Mémoire sur l'occasion de mes écrits, Namur 19922, s. 176. 
b) Opracowanie i zorganizowanie prawa nie jest wprost problemem teologicznym, ale należy do sfery „prawego rozumu - recta ratio". Prawy rozum musi starać się rozeznać, wychodząc poza przejściowe opinie i kierunki myślowe, to, co jest sprawiedliwe, a więc określić to, czym jest prawo samo w sobie. Nieuchronnie musi podjąć on poszukiwania tego, co jest zgodne $\mathrm{z}$ wewnętrznymi wymaganiami i roszczeniami bytu ludzkiego w każdym czasie i miejscu, oraz dążyć do określenia tego, co wyróżnia człowieka, i tego, co jest dla niego destrukcyjne.

Zadaniem wiary i Kościoła jest troska o uzdrowienie „rozumu - ratio” oraz, poprzez odpowiednie wychowanie człowieka, zapewnianie jego rozumowi zdolności widzenia rzeczywistości. Jak nigdy dotąd, Kościół musi stać się obrońcą rozumu przed anarchicznymi i rozmywającymi tendencjami, które pozbawiają go autonomii i zdolności wypowiadania się w sposób obiektywny i uniwersalny. Wystarczająco jasnym dowodem prowadzenia tej obrony w Kościele i jej możliwych kierunków jest encyklika Jana Pawła II Fides et ratio, której kard. Ratzinger był wytrwałym propagatorem.

Jeśli chodzi o powiązanie kwestii prawa z kwestią rozumu, to wydaje się, że nie jest w tej chwili ważne, czy to prawo w sobie, którego należy poszukiwać, ma się nazywać „prawem naturalnym”, czy „prawdą o osobie”, jak mówił papież Jan Paweł II, czy jeszcze inaczej. Jest jednak pewne, że gdzie ten wymóg wewnętrzny bytu ludzkiego, który jako taki jest ukierunkowany na prawo, gdzie ta instancja, która wykracza poza zmienne prądy, nie może być już uchwycona, a więc gdzie „koniec metafizyki” jest całkowity, czyli jest faktem, tam byt ludzki zostaje zagrożony w swojej istocie i godności.

c) Kościół i teologia muszą podjąć rachunek sumienia z destrukcyjnych podejść do prawa, które były związane z jednostronnymi interpretacjami wiary i wywarły destrukcyjny wpływ na historię ubiegłego wieku. A takich interpretacji było wyjątkowo dużo. Orędzie kościoła wykracza poza zakres samego rozumu oraz odsyła do nowych wymiarów wolności i wspólnoty, które rodzą się z tajemnicy Jezusa Chrystusa. Wiara w Stwórcę i Jego stworzenie jest nierozerwalnie związana $\mathrm{z}$ wiarą w Odkupiciela i odkupienie. Jednak odkupienie nie eliminuje stworzenia i jego porządku, ale przeciwnie - przywraca mu możliwość uchwycenia głosu Stwórcy w Jego stworzeniu, a w ten sposób pomaga lepiej rozumieć podstawy prawa. Metafizyka i wiara, natura i łaska, prawo i Ewangelia nie przeciwstawiają się sobie, ale ściśle łączą ze sobą. Miłość chrześcijańska w ujęciu Kazania na Górze nie może stać się podstawą 
prawa państwowego; zdecydowanie wykracza poza to prawo i może być realizowane tylko $\mathrm{w}$ wierze. Jednak nie jest ono przeciwne stworzeniu i jego prawom, gdyż na nim się opiera. Gdzie nie ma prawa, tam również miłość traci swoje życiowe środowisko.

Wiara szanuje więc własną naturę państwa, przede wszystkim państwa w społeczeństwie pluralistycznym, ale czuje także swoją współodpowiedzialność za to, aby podstawy prawa nadal pozostawały widzialne i aby państwo nie zostało pozbawione podstaw odpowiedniego dla niego porządku i nie było wystawione tylko na grę zmiennych prądów, a tym samym by nie uległo destrukcji. 